\title{
Correction
}

\section{LGI1 mutations in autosomal dominant partial epilepsy with auditory features}

In the article "LGI1 mutations in autosomal dominant partial epilepsy with auditory features" (Neurology 2004:62;1120-1126) by Ottman et al., the authors' position of the mutation reported by Fertig et al. (2003) in Figure 1 is incorrect. The correct position of the mutation is $1177 \mathrm{~T}>\mathrm{G}$ (exon 8), counting from the first nucleotide of the mRNA sequence. The authors apologize for this error.

\section{AAN AWARD FOR CREATIVE EXPRESSION OF HUMAN VALUES IN NEUROLOGY}

Dr. Michael Smith of Tucson is the winner of the 2003 AAN Award for Creative Expression of Human Values in Neurology (the "Creative Expression Award"). His prizewinning personal history, "A Wise Owl," appears in the November 11, 2003, issue of Neurology.

At a reception hosted by the Ethics, Law \& Humanities Committee during the 56th Annual Meeting of the AAN in San Francisco, Dr. Smith received a check for $\$ 500$. A donation of $\$ 1500$ has also been given in his honor to the charitable organization of his choice, Doctors without Borders/Médecins sans Frontieres.

To learn more about the Creative Expression Award,

visit http://aan.com/professionals/awards/award/awa_cre_exp.cfm 


\section{Neurology}

\section{LGII mutations in autosomal dominant partial epilepsy with auditory features Neurology 2004;62;2146 \\ DOI 10.1212/WNL.62.11.2146}

\section{This information is current as of June 7, 2004}

\section{Updated Information \&}

Services

Permissions \& Licensing

Reprints including high resolution figures, can be found at: http://n.neurology.org/content/62/11/2146.full

Information about reproducing this article in parts (figures,tables) or in its entirety can be found online at:

http://www.neurology.org/about/about_the_journal\#permissions

Information about ordering reprints can be found online:

http://n.neurology.org/subscribers/advertise

Neurology ${ }^{\circledR}$ is the official journal of the American Academy of Neurology. Published continuously since 1951, it is now a weekly with 48 issues per year. Copyright. All rights reserved. Print ISSN: 0028-3878. Online ISSN: 1526-632X.

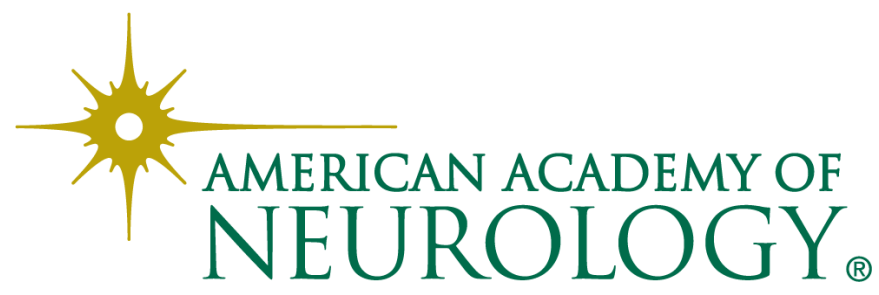

